\section{$\sqrt{2}$ \\ EDITOR'S \\ CHOICE}

\title{
Practice guidance on the management of acute and chronic gastrointestinal problems arising as a result of treatment for cancer
}

\author{
H Jervoise N Andreyev, ${ }^{1}$ Susan E Davidson, ${ }^{2}$ Catherine Gillespie, ${ }^{3}$ William H Allum, ${ }^{1,4}$ \\ Edwin Swarbrick ${ }^{5}$
}

${ }^{1}$ Pelvic Radiation Disease and Gl Unit, Royal Marsden NHS

Foundation Trust, London and Sutton, UK

${ }^{2}$ Clinical Oncology, Christie Hospital NHS Foundation Trust, Manchester, UK

${ }^{3}$ Cancer and Palliative Care, Chelsea and Westminster Hospital, London, UK

${ }^{4}$ Surgery, Royal Marsden NHS Foundation Trust, London, UK and National Clinical Advisor for Upper Gastrointestinal Cancer, NHS Improvements, UK

${ }^{5}$ Gastroenterology, The Royal Wolverhampton NHS Trust, UK

\section{Correspondence to}

Dr Jervoise Andreyev,

Consultant Gastroenterologist in Pelvic Radiation Disease, Royal Marsden NHS Foundation Trust, London SW3 6JJ, UK: j@andreyev.demon.co.uk

Produced on behalf of the British Society of Gastroenterology, the Association of Colo-Proctology of Great Britain and Ireland, the Association of Upper

Gastrointestinal Surgeons and the Faculty of Clinical Oncology Section of the Royal College of Radiologists.

The President of the British Society of Gastroenterology commissioned this document following a request from Professor Sir Mike Richards, National Cancer Director, and Professor Jane Maher, Chief Medical Officer of Macmillan Cancer Support and Chair of the National Cancer Survivorship Initiative's Consequences of Treatment Group.

Revised 19 September 2011 Accepted 29 September 2011 Published Online First

4 November 2011

This paper is freely available online under the BMJ Journals unlocked scheme, see http:// gut.bmj.com/site/about/ unlocked.xhtml

\section{ABSTRACT}

Backgound The number of patients with chronic gastrointestinal (GI) symptoms after cancer therapies which have a moderate or severe impact on quality of life is similar to the number diagnosed with inflammatory bowel disease annually. However, in contrast to patients with inflammatory bowel disease, most of these patients are not referred for gastroenterological assessment. Clinicians who do see these patients are often unaware of the benefits of targeted investigation (which differ from those required to exclude recurrent cancer), the range of available treatments and how the pathological processes underlying side effects of cancer treatment differ from those in benign Gl disorders. This paper aims to help clinicians become aware of the problem and suggests ways in which the panoply of syndromes can be managed.

Methods A multidisciplinary literature review was performed to develop guidance to facilitate clinical management of $\mathrm{Gl}$ side effects of cancer treatments. Results Different pathological processes within the $\mathrm{Gl}$ tract may produce identical symptoms. Optimal management requires appropriate investigations and coordinated multidisciplinary working. Lactose intolerance, small bowel bacterial overgrowth and bile acid malabsorption frequently develop during or after chemotherapy. Toxin-negative Clostridium difficile and cytomegalovirus infection may be fulminant in immunosuppressed patients and require rapid diagnosis and treatment. Hepatic side effects include reactivation of viral hepatitis, sinusoidal obstruction syndrome, steatosis and steatohepatitis. Anticancer biological agents have multiple interactions with conventional drugs. Colonoscopy is contraindicated in neutropenic enterocolitis but endoscopy may be life-saving in other patients with Gl bleeding. After cancer treatment, simple questions can identify patients who need referral for specialist management of $\mathrm{Gl}$ symptoms. Other troublesome pelvic problems (eg, urinary, sexual, nutritional) are frequent and may also require specialist input. The largest group of patients affected by chronic Gl symptoms are those who have been treated with pelvic radiotherapy. Their complex symptoms, often caused by more than one diagnosis, need systematic investigation by gastroenterologists when empirical treatments fail. All endoscopic and surgical interventions after radiotherapy are potentially hazardous as radiotherapy may induce significant local ischaemia. The best current evidence for effective treatment of radiation-induced GI bleeding is with sucralfate enemas and hyperbaric oxygen therapy.

Conclusions All cancer units must develop simple methods to identify the many patients who need help

\section{Key facts}

- There has been a threefold increase in the numbers of survivors of cancer in the last 30 years

- Chronic gastrointestinal side effects are a common cause of morbidity and reduced quality of life

- Side effects of treatment are frequently missed or overlooked because the current priority of cancer follow-up is to perform surveillance for recurrent cancer

- Individual GPs are unlikely to have many patients with complex problems after cancer therapy and so will require guidance if these patients are to be optimally managed

- Symptoms can often be alleviated or cured.

and establish routine referral pathways to specialist gastroenterologists where patients can receive safe and effective treatment. Early contact with oncologists and/ or specialist surgeons with input from the patient's family and friends often helps the gastroenterologist to refine management strategies. Increased training in the late effects of cancer treatment is required.

\section{BACKGROUND}

Improvements in the outcome for patients with cancer over the last 30 years have reflected earlier diagnosis and advances in multimodality treatments. There has been a threefold increase in survival and, although some patients are not cured, their cancer is controlled, often for very long periods. Others may be cured but suffer side effects of their otherwise successful therapies. The National Survivorship Initiative ${ }^{1}$ has identified four key needs of cancer survivors:

1. a personalised 'survivorship' care plan formulated for each patient on completion of treatment;

2. support to self-manage their condition if appropriate;

3. provision of information on long-term effects of living with and beyond cancer;

4. access to specialist medical care for complications that occur after cancer. 
Potentially serious complications are an inevitable consequence of radical therapies. Profound fatigue is not unusual; emotional and psychological difficulties are common. However, of the two million people currently living with or cured of cancer in the UK, $25 \%$ report chronic physical problems following treatment which impair their quality of life. ${ }^{1-3}$

Gastrointestinal (GI) symptoms are the most common of all the chronic physical side effects of cancer treatment and have the greatest impact on quality of life. ${ }^{4}$ Fewer than $20 \%$ of affected patients are referred to a GI specialist ${ }^{5}$ because clear management algorithms and routine referral pathways are not in place and the treatable aspects of the symptom complexes go unrecognised. When patients are referred, they usually meet a clinician who has had no formal training in the management of late effects of cancer treatment. Clinicians are further hampered by limited research into the range of problems or their optimal treatment, ${ }^{67}$ and few gastroenterologists or GI surgeons feel confident in managing such patients. ${ }^{5}$ As a result, these patients need-but fail to get-appropriate assessment. ${ }^{8}$ Ineffective and potentially harmful treatments are prescribed, ${ }^{1} 679$ and some patients may be forced unnecessarily to withdraw from work and society. ${ }^{10}$ Sometimes continuing symptoms compromise or prevent ongoing anticancer treatment. In a few patients, chronic symptoms mask the early diagnosis of recurrent or second cancers.

This guidance has been designed to facilitate clinical practice. It focuses on the physical causes of symptoms rather than the psychological, because gastroenterologists are already very familiar with identifying psychological factors in GI disease. While these patients are exposed to a unique set of psychological stresses which in turn may produce GI symptoms, there are robust data that organic causes for symptoms are frequently missed. This guidance will therefore emphasise those areas where symptoms starting after cancer treatments can be considered in the same way as other GI diseases and when clinicians need to be wary. It defines principles of management where possible and outlines research priorities for the future. There is very little level A (randomised controlled trial) or level B (outcomes research) evidence to define optimal management of these patients or to produce definitive guidelines. In the absence of anything better, the recommendations presented in this guidance to inform practical approaches to treatment are largely based on level $\mathrm{C}$ (case series) and level D (expert opinion, physiological and laboratory studies) data.

\section{PATHOPHYSIOLOGY OF SIDE EFFECTS OF CANCER THERAPIES Chemotherapy}

Cytotoxic chemotherapy agents have a direct effect on the GI mucosa causing inflammation, ${ }^{11-13}$ oedema, ulceration and atrophy. Increased bowel permeability combined with the secondary effects of immunosuppression predispose to increased susceptibility to GI transmural infection potentially leading to septicaemia, shock, associated hypotension and secondary mucosal ischaemia.

New-onset lactose intolerance is the cause of diarrhoea and bloating during 5-fluorouracil chemotherapy in $10 \%$ of patients. ${ }^{14} 15$ Clinical experience suggests that small bowel bacterial overgrowth, bile acid malabsorption and pancreatic insufficiency are three other important contributory factors to chemotherapy-induced GI symptoms. ${ }^{16}$

Hepatic side effects include reactivation of hepatitis $\mathrm{B},{ }^{17}$ severe sinusoidal obstruction syndrome (especially oxaliplatin- based regimens $)^{18}$ and steatosis. Following treatment with irinotecan in particular, steatosis may progress to steatohepatitis. ${ }^{19}$ This may be exacerbated by pre-existing conditions (eg, alcohol excess, diabetes and obesity). Both steatosis and steatohepatitis are potentially reversible after cessation of chemotherapy but occasionally contribute to morbidity and mortality. ${ }^{18-21}$ The detailed management of these conditions is described elsewhere. ${ }^{22}$

Chronic GI side effects of chemotherapy have not been studied systematically or prospectively. Clinical experience suggests that a small proportion of patients do have ongoing GI problems with constipation, diarrhoea, flatulence, bloating and pain, and that small bowel bacterial overgrowth is a frequent cause of these symptoms. However, specific drugs, their cumulative dose, the degree of immunosuppression during treatment together with the degree of damage to the mucosa, submucosa and GI stem cells may also play a role in the development of chronic problems. ${ }^{16} 23$ The interaction with other cancer treatments complicates the clinical picture further.

\section{Biological agents}

Rapidly increasing numbers of biological agents are being introduced for cancer therapy. This includes both immunotherapy and inhibitors of specific molecular targets. The main categories of targeted therapies currently include tyrosine kinase inhibitors (eg, erlotinib, imatinib, gefitinib, sorafenib), proteasome inhibitors (eg, velcade) and anti-angiogenesis agents (eg, bevacizumab). The spectrum of GI toxicity with these agents and their causes are poorly defined. Biological agents have multiple interactions with conventional drugs and, when new drugs are prescribed, the potential for interactions must always be checked. It is particularly important for gastroenterologists to know that altering gastric $\mathrm{pH}$ in a patient taking a biological agent orally can markedly affect its bioavailability. In the emergency setting, if there is any possibility that the biological agent is the cause of severe symptoms, it is always acceptable that the agent should be stopped while waiting for urgent advice from the oncologist treating the patient. Acute severe GI symptoms should otherwise be managed normally.

\section{Radiotherapy}

Radiotherapy initially causes mucosal changes characterised by inflammation or cell death, but subsequently persistent cytokine activation in the submucosa leads to progressive ischaemia, fibrosis and loss of stem cells. ${ }^{24}$ These ischaemic and fibrotic changes potentially cause impairment of GI physiological function(s). Chemotherapy increases the sensitivity of noncancerous tissues to damage from radiotherapy. Chronic GI dysfunction may follow without pause from acute symptoms induced by radiotherapy or may arise de novo months, years or even decades later. The time allowed for follow-up in most studies prevents the recognition of these late side effects, their frequency or severity. ${ }^{25}$

It is argued that introduction of new chemotherapy and biological agents and more targeted radiotherapy techniques over the last two decades will diminish toxicity rates, ${ }^{26} 27$ but the long-term effects of these new cancer treatments are unknown. ${ }^{28}$ For example, the technique of intensity-modulated radiotherapy (IMRT) has been introduced widely. One possibly important consequence of IMRT is that more organs are exposed to low-dose irradiation than was the case with conventional treatment. It will be some time before definitive evidence from clinical trials shows the true impact of this on 
acute and chronic toxicity. Clinical experience suggests that IMRT simply changes the timing and spectrum of toxicity. There are virtually no data on the long-term effects of even newer techniques such as proton beam therapy and cyber knife treatment.

\section{Surgery}

Radical resectional surgery may cause significant disruption of GI physiology. This includes disturbance in intestinal transit, altered gastric emptying, enzymatic digestion and malabsorption reflecting anatomical disruption and stasis, bacterial overgrowth, altered bile acid secretion and absorption and hepatic insufficiency. Hepatopancreatobiliary resections carry the inherent risk of subsequent biliary strictures (which may be due either to benign fibrosis at the anastomosis or disease recurrence) resulting in obstructive jaundice. In the past, many patients had limited survival after primary cancer surgery but symptom complexes which were common-for example, after upper GI surgery for peptic ulceration-are now being observed in longterm cancer survivors, although many clinicians will no longer be familiar with these.

\section{Non-resectional ablation techniques}

Radiofrequency or microwave ablation and tumour embolisation with a variety of agents including radioactive beads are being used increasingly with both palliative and curative intent to treat liver tumours. Complications include bleeding, ulceration, ischaemia or perforation of adjacent bowel, abscess formation, hepatic artery aneurysm and tumour track seeding.

\section{GI SYMPTOMS: THE ACUTE SYNDROMES}

The presentation of GI side effects can be acute, subacute or chronic (table 1).

Many acute and subacute problems related to cancer treatments will be managed by oncologists. However, increasingly, potentially life-threatening complications of modern treatments present via emergency departments. ${ }^{29}$

\section{Acute syndromes: key facts}

Urgent cross-sectional imaging may help assessment and management

- Perform early upper GI endoscopy and duodenal biopsies and duodenal aspirate and lower Gl endoscopy with biopsies for diarrhoea

- Flexible sigmoidoscopy rather than colonoscopy is usually adequate initially

- Always consider taking biopsies and asking for histological evidence of viral infection, especially if multiple ulcers are seen, even if there has been bleeding

- Ensure platelet support is available before endoscopic intervention when the platelet count is below $80 \times 10^{9}$

- Avoid biopsies from areas of obvious radiation-induced change unless absolutely necessary

- Colonoscopy is contraindicated in neutropenic enterocolitis

- Infections in the neutropenic patient can kill quickly; early empirical treatment may be required

- Seek early specialist help

\section{Infection}

Neutropenic sepsis is a common complication of cancer chemotherapy precipitating GI symptoms, which usually respond quickly to antibiotics. In patients with worsening or severe diarrhoea, one single stool specimen is sufficient for the detection of bacteria or toxins, however three separate specimens are required to exclude parasitological causes with sufficient diagnostic sensitivity. Early endoscopic assessment is also mandatory as stool culture may not detect viral infection, toxin-negative Clostridium difficile or drug-induced colitis. Endoscopy in a neutropenic patient predisposes to sepsis, although the degree of the increased risk is unclear. Febrile neutropenic patients should already be on antibiotic therapy. Recent British Society of Gastroenterology guidelines (grade C

Table 1 Presentation of gastrointestinal side effects: acute, subacute or chronic

\begin{tabular}{|c|c|c|c|}
\hline Aetiology & Acute & Subacute & Chronic \\
\hline Infection & $\begin{array}{l}\text { Bacterial } \\
\text { Viral } \\
\text { Fungal } \\
\text { Opportunistic }\end{array}$ & $\begin{array}{l}\text { Small bowel bacterial } \\
\text { overgrowth }\end{array}$ & $\begin{array}{l}\text { Small bowel bacterial } \\
\text { overgrowth }\end{array}$ \\
\hline $\begin{array}{l}\text { Inflammation } \\
\text { (acute) }\end{array}$ & $\begin{array}{l}\text { Neutropenic enterocolitis } \\
\text { Perforation } \\
\text { Haemorrhage } \\
\text { Graft versus host disease } \\
\text { Pancreatic insufficiency }\end{array}$ & Graft versus host disease & Graft versus host disease \\
\hline $\begin{array}{l}\text { Inflammation } \\
\text { (chronic) }\end{array}$ & & $\begin{array}{l}\text { Bowel obstruction/strictures, } \\
\text { Pancreatic insufficiency }\end{array}$ & Graft versus host disease \\
\hline Ischaemic/fibrotic & Gastric outflow obstruction & $\begin{array}{l}\text { Graft versus host disease, } \\
\text { Pancreatic insufficiency }\end{array}$ & $\begin{array}{l}\text { Biliary strictures } \\
\text { Bowel obstruction } \\
\text { Enteropathy and loss } \\
\text { of physiological functions } \\
\text { Graft versus host disease } \\
\text { Pancreatic insufficiency }\end{array}$ \\
\hline Metabolic & $\begin{array}{l}\text { Malabsorption } \\
\text { Hepatic insufficiency }\end{array}$ & Malabsorption & Malabsorption \\
\hline $\begin{array}{l}\text { Vascular } \\
\text { (ischaemia) }\end{array}$ & $\begin{array}{l}\text { Mesenteric vascular } \\
\text { insufficiency } \\
\text { Mesenteric thrombosis } \\
\text { Veno-occlusive disease }\end{array}$ & & $\begin{array}{l}\text { Enteropathy and loss of } \\
\text { physiological functions }\end{array}$ \\
\hline $\begin{array}{l}\text { Vascular } \\
\text { (proliferative) }\end{array}$ & & & Telangiectasia causing bleeding \\
\hline
\end{tabular}


evidence: expert opinion) suggest that afebrile patients with a neutrophil count $<0.5 \times 10^{9} / 1$ need to be offered antibiotic prophylaxis only for GI endoscopic procedures associated with high risk of bacteraemia such as variceal sclerotherapy, oesophageal dilation, laser therapy and endoscopic retrograde cholangiopancreatography with biliary obstruction. Gram-negative aerobic (and, less frequently, anaerobic) bacteria including Escherichia coli are the most likely pathogens in these conditions, and the choice of prophylactic antibiotics should reflect the local sensitivities of organisms. ${ }^{30}$

The two most important treatable pathogens which regularly cause severe morbidity or death in patients receiving treatment for cancer are cytomegalovirus (CMV) and C difficile (10\% are toxin-negative). The type of endoscopic assessment which best identifies stool culture-negative pathogens is not clearly defined. However, upper GI endoscopy with duodenal biopsies and aspirate and flexible sigmoidoscopy with left colonic biopsies seem to produce results equivalent to full colonoscopy and ileal biopsy ${ }^{16} 3132$ while avoiding the need for full bowel preparation and reducing risk.

CMV infection may affect the whole GI tract but is most commonly found in the oesophagus and colon. Common symptoms include diarrhoea (up to $80 \%$ ), bleeding (up to $64 \%$ ), fever (up to $50 \%$ ) and abdominal pain (19-50\%). Endoscopy may demonstrate the presence of multiple ulcers. Serology, viral culture and PCR techniques are not reliably positive for 3 or 4 weeks after the onset of symptoms. Earlier diagnosis may be available using the newer shell vial assay and from examination of endoscopic biopsies. Biopsies should be taken both from the centre/base of ulcers (site of highest yield for CMV) and from the edge (which gives a higher yield in herpes simplex virus infection). ${ }^{33} 34$ In a sick immunosuppressed patient with relevant symptoms, early empirical treatment with ganciclovir should be considered.

The typical endoscopic appearance of $C$ difficile at flexible sigmoidoscopy is often diagnostic in toxin-negative patients. However, pseudomembrane formation requires neutrophil involvement, and the typical macroscopic and microscopic appearance may be altered or be completely absent in neutropenic patients. ${ }^{35}$ Immunosuppressed patients with $C$ difficile are at high risk of early progression to fulminant toxic megacolon, so delay in investigation and treatment is potentially dangerous.

Many other pathogens including amoebae, giardia, viruses such as herpes simplex virus, rotavirus or adenovirus, bacterial pathogens and fungi may be responsible for symptoms. Recurrent infections with different organisms in immunosuppressed patients may mandate repeated endoscopic reassessments at short intervals. More than one pathogen may be responsible.

Anorectal sepsis in neutropenic patients is a frequently forgotten cause of morbidity. Clinical assessment by an experienced colorectal surgeon supplemented by MRI scanning can often be helpful in detecting an occult site for recurrent infection.

\section{Typhlitis and neutropenic enterocolitis}

Typhlitis and neutropenic enterocolitis carry a high mortality rate because of the risk of rapid progression to ischaemia, necrosis, haemorrhage, perforation and multisystem organ failure. Typhlitis follows chemotherapy-induced neutropenia and is characterised by inflammation localised to the caecal wall, possibly caused by bacterial invasion. If other parts of the GI tract are involved (eg, the terminal ileal wall or elsewhere), the term 'neutropenic enterocolitis' is more appropriate. Bowel wall thickening with or without dilation is usually seen on crosssectional imaging. Clinical features include fever, abdominal pain, nausea, vomiting and diarrhoea. Colonoscopy is contraindicated as it carries a very high risk of perforation.

Data on the optimal management are limited. Bowel rest, intravenous fluids, parenteral nutrition, broad spectrum antibiotics and normalisation of neutrophil counts are usually recommended. ${ }^{36}$ When inflammation is limited to the caecum and terminal ileum, clinical experience suggests that most patients can be managed conservatively. The presence of a local mass needs repeated imaging to exclude abscess formation or perforation. Perforation, persistent GI bleeding and clinical deterioration may mandate surgical intervention. As in the management of any acute severe colitis, frequent clinical reassessment and early surgical consultation is advised.

\section{Haemorrhage}

Causes of bleeding include chemotherapy-induced ischaemia (particularly induced by taxanes ${ }^{13} 37$ and bevacizumab ${ }^{38}$ ), infections (particularly CMV and Candida), graft versus host disease (which can occur after stem cell transplantation when the newly transplanted material attacks the transplant recipient's body), autoimmune colitis after treatment with ipilimumab, ${ }^{11}$ acute radiotherapy-induced ulceration, drug-or radiotherapy-induced inflammatory bowel disease, neutropenic enterocolitis and oxaliplatin-induced portal hypertension. ${ }^{39}$ Patients should be managed like any other high-risk GI bleed. Experienced endoscopists must be involved from the onset. Although endoscopy may be more hazardous, early endoscopic therapy may also be life-saving.

Thrombocytopenia is common in patients with cancer undergoing chemotherapy. Endoscopists should be aware that, even with apparently adequate platelet counts, chemotherapyinduced platelet dysfunction may affect normal homeostatic mechanisms. There are no robust data as to the minimal safe platelet count for safe therapeutic endoscopy. Endoscopists should consider ensuring in advance that platelet support is available should it be required when performing therapeutic procedures in patients with a platelet count below 50-80 000/ $\mu 1$.

The endoscopic appearance may not be diagnostic without biopsy. However, even flexible endoscopic biopsy under direct vision can be hazardous in the presence of thrombocytopenia, incipient ischaemic necrosis or previous radiotherapy, especially brachytherapy. Endoscopic intervention may be sufficient for bleeding from discrete sites, but interventional radiology with embolisation or surgery may be required in extensive mucosal change. Hyperbaric oxygen therapy is probably the treatment of choice for radiotherapy-induced bleeding occurring at multiple sites throughout the small and/or large bowel. $^{40-42}$

\section{Perforation}

Perforation may result from spontaneous tumour necrosis, which may or may not be due to chemotherapy or progression of cytotoxic drug-induced ulceration, often on a background of adjunctive corticosteroid or non-steroidal anti-inflammatory drug treatment. The antivascular endothelial growth factor monoclonal antibody bevacizumab causes ulceration, fistulation or free perforation in $0.9 \%$ of patients within 1 year of treatment. ${ }^{43}$ This may be at the primary tumour site but also within colonic diverticula or otherwise normal areas of stomach and duodenum. Bevacizumab may increase the risk of stentrelated $^{44}$ and spontaneous perforation and is associated with bleeding, poor wound healing and thromboembolism. Two 
tyrosine kinase inhibitors, erlotinib and gefitinib, are also associated with bowel perforation. Surgical treatment is essential as long as the patient is fit enough, and therapeutic resection may be the best approach if the primary tumour has perforated. If circumstances permit, referral to a specialist surgeon is indicated.

\section{Mesenteric ischaemia and infarction}

Spontaneous mesenteric vascular insufficiency can be induced by the hypercoagulable state associated with some cytotoxic agents. ${ }^{45}$ This can affect both diseased and unaffected small bowel. The mortality rate is high and a high degree of suspicion is needed to diagnose ischaemia. The aetiology may be venous or arterial and expert radiology may help in assessment and management. Optimal management of acute intestinal ischaemia requires early assessment by an experienced surgical team. The options-depending on the general state of the patient-include full anticoagulation if the bowel is viable, through to staged resection, often requiring repeat laparotomies and open abdomen techniques.

Chemotherapy-associated mesenteric ischaemia can present with acute abdominal pain, but also can produce small bowel strictures causing small bowel obstruction. It must be treated by a combination of nutritional support, repeated clinical assessment by experienced surgeons and appropriate anticoagulation.

\section{Hepatic veno-occlusive disease/portal vein thrombosis}

This is a very frequent cause of early mortality among patients receiving high-dose chemoradiation or stem cell transplantation. ${ }^{46}$ Activation of the coagulation cascade and inflammatory processes following endothelial injury results in a hypercoagulable state. The possibility must always be considered in patients presenting with jaundice, pain or ascites. Many patients will, however, have rather non-specific symptoms or biochemical changes and early CT scanning with contrast may be diagnostic. Early anticoagulation may be life-saving.

\section{Bowel obstruction}

Obstruction usually affects the small bowel or, after pelvic radiotherapy, the sigmoid. Several factors may contribute in individual patients. It may develop as a result of benign causes such as changes in intestinal transit, medical causes (see below), adhesions or radiotherapy-induced fibrosis, or malignant causes such as recurrent cancer or peritoneal carcinomatosis.

\section{Acute small bowel obstruction}

This should be managed conservatively initially with analgesia, intravenous fluids, nutritional support and nasogastric aspiration unless there is suspicion of strangulation requiring emergency surgery. Cross-sectional imaging, which sometimes is difficult to interpret accurately, may be helpful to estimate the level of obstruction and whether it is complete or incomplete. The possibility of multiple sites of partial obstruction needs to be carefully considered as this may limit surgical options.

\section{Subacute bowel obstruction}

Experience suggests that important medical causes include abnormal electrolyte balance, opioid drugs, small bowel bacterial overgrowth, excessive faecal loading, severe fat malabsorption and excessive dietary fibre.

A trial of antibiotics and/or a low-fat diet (if steatorrhoea is present) and/or treatment with a bile acid sequestrant as appropriate may help. If the radiology suggests focal colonic faecal loading or a colonic site of obstruction or there is iron deficiency anaemia, colonoscopy should be considered. Excess fibre in the diet may precipitate subacute obstruction if a stricture is present. Some patients are very sensitive to opiates and can have prolonged colonic inertia even following small doses.

If low-fibre diets are indicated they should be prescribed by a qualified dietitian, should initially be time limited and the clinical benefit from the diet reviewed. Additional laxatives may be required. Data may emerge for the role of hyperbaric oxygen in treating patients with subacute obstruction due to radiationinduced fibrosis from the national ongoing HOT 2 trial (EudraCT No 2008-002152-26).

Surgery with a view to releasing adhesions or resecting strictures after previous pelvic radiotherapy can be particularly challenging because of dense abdominal fibrosis, and carries significantly higher risks of complications (eg, anastomotic leakages, postoperative intra-abdominal sepsis and intestinal fistulation) than surgery in a non-irradiated patient. Such surgery should be performed only by experienced surgeons with a low threshold for proximal faecal diversion. If an enteric motility disorder is also present (not uncommon), surgery may not lead to resolution of the symptoms.

\section{Obstruction due to recurrent cancer}

If cancer is present, the nature of the intervention should be influenced by the expected prognosis of the recurrence. Selected patients with no ascites, life expectancy $>2$ months and good performance status may benefit from palliative decompressive surgery, but placement of self-expanding metal stents (if possible) appears to offer a better outcome. ${ }^{47}$ Expert medical management with opioids, antispasmodics (eg, hyoscine butyl bromide), antiemetics, antisecretory agents (eg, octreotide), corticosteroids and nasogastric tubes or venting gastrostomies can be effective in helping to control symptoms. Early input from surgeons and palliative care specialists should be sought. ${ }^{48}$

\section{GI SYMPTOMS: THE CHRONIC SYNDROMES}

The GI tract can only respond to pathological processes in a limited number of ways, so different pathological processes may produce identical symptoms. Many patients treated for cancer have other pre-existing illnesses and lifestyles which predispose to cancer and also to chronic GI symptoms after cancer treatments. ${ }^{16} 49$ New incidental GI conditions may develop or manifest themselves coincidentally around the time the cancer is treated or thereafter. Patients may be taking medications or have made dietary changes affecting GI function.

There are ample data to suggest that symptom clusters often labelled as 'typical syndromes'-for example, 'bleeding from

\section{Chronic syndromes: key facts}

Symptoms are unreliable at identifying the underlying cause

- Many cancer treatments have systemic effects and are not limited by normal anatomical boundaries

- Patients may not report even severe symptoms reliably

- Patients and clinicians may differ as to what constitute significant symptoms. 
proctitis' or 'subacute obstruction due to adhesions'-are unreliable at predicting the true underlying cause of symptoms. ${ }^{50-55}$ Part of the reason for this is that many cancer treatments are systemic and do not respect conventional anatomical boundaries. One-third of symptoms confidently attributed to cancer therapy are found after investigation to be unrelated to the cancer treatment. ${ }^{51}$ A more valuable approach is to pay attention to the full clinical picture and consider all options. ${ }^{50} 51$

\section{Incidence and prevalence figures}

GI side effects are underestimated in the literature and within clinical trials. ${ }^{56-58}$ Case notes frequently do not record side effects except when patients require surgery as part of their management. ${ }^{59} 60$ When prospective data are available, ${ }^{3}$ they are invariably based on symptom questionnaires rather than objective markers. Many current questionnaires are inadequately sensitive, do not use reproducible methodology and ignore issues important for patients-for example, severe flatulence or urgency of defaecation. ${ }^{49}{ }^{61-65}$ Focusing on symptoms without confirmatory objective investigations is also potentially misleading. Common bowel disorders produce identical symptoms to those arising as side effects of cancer therapies. $^{3} 4966$ There is an urgent need for better tools which can be applied in routine clinical practice to measure side effects accurately. ${ }^{67}$

\section{Clinician, patient and treatment factors}

Some patients will not report symptoms because they are too embarrassed or feel nothing can be done. ${ }^{10}$ Clinicians may not understand the significance of patients' symptoms or their relationship to previous cancer treatments or simply ignore them. ${ }^{61}$ Health professionals seeing these patients need to develop strategies to identify proactively unexpected symptoms potentially amenable to treatment.

Different problems and rates of late effects occur depending on specific treatments and how they are combined. Table 2 shows the rate and nature of problems for a wide variety of cancers and table 3 shows how different treatments for the same cancer can have different toxicity profiles.

The non-specific nature of these post-treatment symptoms, which often occur in combination, requires a systematic approach to unravel the associated, sometimes complex, clinical causes. In patients attending a specialist clinic for late GI effects after cancer therapy, more than half were found to have more than one cause for their symptoms. ${ }^{50}$ For each specific symptom there are a number of potential diagnoses. Using a systematic

Table 2 Rate and nature of chronic gastrointestinal problems after cancer treatment in patients at different tumour sites

\begin{tabular}{|c|c|c|c|c|c|c|}
\hline $\begin{array}{l}\text { Cancer } \\
\text { site }\end{array}$ & $\begin{array}{l}\text { Numbers of } \\
\text { diagnoses } \\
\text { annually in UK }\end{array}$ & $\begin{array}{l}\text { Numbers } \\
\text { undergoing } \\
\text { treatment with } \\
\text { curative intent }\end{array}$ & $\begin{array}{l}\text { Treatment } \\
\text { modalities }\end{array}$ & $\begin{array}{l}\text { Survival at } 5 \text { years } \\
\text { after radical treatment }\end{array}$ & $\begin{array}{l}\text { Percentage } \\
\text { affected by chronic } \\
\text { symptoms affecting } \\
\text { quality of life }\end{array}$ & $\begin{array}{l}\text { Types of chronic } \\
\text { Gl symptoms }\end{array}$ \\
\hline Oesophago-gastric & 13000 & $20 \%$ & $\begin{array}{l}\text { Chemotherapy } \\
\text { Radiotherapy } \\
\text { Surgery }\end{array}$ & $25-30 \%$ & $50 \%(?)$ & $\begin{array}{l}\text { Anorexia } \\
\text { Diarrhoea } \\
\text { Nausea } \\
\text { Reflux } \\
\text { Weight loss }\end{array}$ \\
\hline Pancreas & 6500 & $10-15 \%$ & $\begin{array}{l}\text { Chemotherapy } \\
\text { Radiotherapy } \\
\text { Surgery }\end{array}$ & $14 \%-25 \%$ & $\mathrm{~N} / \mathrm{A}$ & $\begin{array}{l}\text { Malabsorption } \\
\text { Weight loss } \\
\text { Wind }\end{array}$ \\
\hline Colorectal & 38600 & $90 \%$ & $\begin{array}{l}\text { Chemotherapy } \\
\text { Radiotherapy } \\
\text { Surgery }\end{array}$ & $50 \%$ & $\begin{array}{l}\text { Colonic surgery: } 15 \% \\
\text { Rectal surgery: } 33 \% \\
\text { Short-course radiotherapy: } \\
66 \% \\
\text { Chemoradiation }+ \\
\text { surgery: } 50 \%\end{array}$ & $\begin{array}{l}\text { Bleeding } \\
\text { Diarrhoea } \\
\text { Frequency } \\
\text { Incontinence } \\
\text { Tenesmus } \\
\text { Urgency }\end{array}$ \\
\hline Anal & 1000 & $80 \%$ & $\begin{array}{l}\text { Chemoradiation } \\
\text { (Surgery) }\end{array}$ & $40 \%-70 \%$ & N/A & $\begin{array}{l}\text { Bleeding } \\
\text { Frequency } \\
\text { Incontinence } \\
\text { Urgency }\end{array}$ \\
\hline Gynaecological & 18000 & $90 \%$ & $\begin{array}{l}\text { Surgery } \\
\text { Radiotherapy } \\
\pm \text { Chemotherapy }\end{array}$ & $\begin{array}{l}\text { Variable } \\
\text { Depending } \\
\text { on tumour type }\end{array}$ & $\begin{array}{l}40 \% \text { after treatment which } \\
\text { includes radiotherapy }\end{array}$ & $\begin{array}{l}\text { Bleeding } \\
\text { Diarrhoea } \\
\text { Flatulence } \\
\text { Frequency } \\
\text { Incontinence } \\
\text { Malabsorption } \\
\text { Pain } \\
\text { Urgency }\end{array}$ \\
\hline Head and neck & 9000 & $90 \%$ & $\begin{array}{l}\text { Chemoradiation } \\
20-25 \% \\
\text { Surgery }\end{array}$ & $>50 \%$ & Up to $50 \%$ & $\begin{array}{l}\text { Dysgeusia } \\
\text { Dysphagia } \\
\text { Dependency on } \\
\text { tube feeding } \\
\text { Pain } \\
\text { Trismus } \\
\text { Weight loss } \\
\text { Xerostomia }\end{array}$ \\
\hline Urological & 50000 & $80 \%$ & $\begin{array}{l}\text { Chemotherapy } \\
\text { Radiotherapy } \\
\text { Surgery }\end{array}$ & $75 \%$ & $30 \%$ after radiotherapy & $\begin{array}{l}\text { Bleeding } \\
\text { Constipation } \\
\text { Diarrhoea } \\
\text { Flatulence } \\
\text { Frequency } \\
\text { Incontinence } \\
\text { Malabsorption } \\
\text { Pain } \\
\text { Urgency }\end{array}$ \\
\hline
\end{tabular}


Table 3 Frequency of chronic toxicity from different treatments for rectal cancer

\begin{tabular}{llll}
\hline Symptoms & $\begin{array}{l}\text { Surgery } \\
\text { alone }\end{array}$ & $\begin{array}{l}\text { Preoperative } \\
\text { radiotherapy }\end{array}$ & $\begin{array}{l}\text { Postoperative } \\
\text { radiotherapy }\end{array}$ \\
\hline Any incontinence & $5-38 \%$ & $51-72 \%$ & $49-60 \%$ \\
Toilet dependency & $6 \%$ & $30 \%$ & $53 \%$ \\
Loose stool & $2-5 \%$ & $\mathrm{~N} / \mathrm{A}$ & $25-29 \%$ \\
Bowel obstruction & $4-11 \%$ & $5-13 \%$ & $11-15 \%$ \\
$\begin{array}{l}\text { Excellent bowel } \\
\text { function }\end{array}$ & $32 \%$ & $14 \%$ & $\mathrm{~N} / \mathrm{A}$ \\
\hline
\end{tabular}

Data compiled from a number of references. ${ }^{80-93}$

algorithmic approach, there are standard tests which may elucidate the diagnosis or diagnoses causing each specific symptom. 350519495 For each diagnosis made, a number of possible established and experimental therapies are available. Anecdotal evidence suggests that such a systematic approach can improve symptoms by an average of $70-90 \%$. The efficacy of such an algorithmic approach in patients with GI symptoms after pelvic radiotherapy is currently being tested in a large, almost completed, randomised clinical trial (ORBIT study, ISRCTN 22890916).

\section{HISTORY, EXAMINATION, INVESTIGATIONS AND TREATMENT}

To date, there has been no coordinated approach to improve the lot of this group of patients. Health professionals who regularly see these patients-medical and clinical oncologists, GI, urological and gynaecological surgeons, specialist nurses and general practitioners-may not have the expertise to manage these patients' symptoms optimally. However, when they identify patients who need and want help-and table 4 suggests that almost all the patients who would benefit from help can be identified with just three simple questions-they must have an established referral pathway for those patients. Most patients should be referred to gastroenterologists but appropriate referral pathways, either to regional centres or locally, are best developed after discussion within the local cancer multidisciplinary team.

\section{Managing symptoms}

A systematic approach to managing symptoms will only function usefully if a clinician can clearly elicit an accurate history from the symptomatic patient who has often undergone complex multimodal treatments. Many patients do not understand precisely the details of previous cancer treatments, which sometimes have gone on for years and may still be continuing,

\section{General management strategies: key facts}

- Gastrointestinal symptoms identified as starting after cancer treatment are frequently not related to the cancer treatment

- Many patients have more than one cause for symptoms

- Many cancer treatments are systemic and may cause side effects throughout the gastrointestinal tract

- Symptoms are unreliable at predicting the underlying cause

- Inappropriate treatment has a significant potential for causing harm (box 5)

- Most patients need appropriate investigation before treatment

- Contacting the oncologists and surgeons for details of previous treatments frequently changes management.
Table 4 Questions to identify patients in need of specialist assessment

\begin{tabular}{ll}
\hline $\begin{array}{l}\text { Critical minimal questions } \\
\text { indicating need for GI referral }\end{array}$ & $\begin{array}{l}\text { Critical minimal indicators to } \\
\text { consider endoscopic assessment }\end{array}$ \\
\hline $\begin{array}{l}\text { Are they woken from sleep to } \\
\text { defaecate? }\end{array}$ & $\begin{array}{l}\text { Is the patient } \geq 5 \text { years after radiotherapy } \\
\text { (screening for second malignancy)? }\end{array}$ \\
$\begin{array}{l}\text { Do they have troublesome urgency } \\
\text { of defaecation and/or faecal }\end{array}$ & Is there any rectal bleeding? \\
leakage/soiling/incontinence? & \\
$\begin{array}{l}\text { Do they have any Gl symptoms } \\
\text { preventing them from living a full life? }\end{array}$ & \\
\hline
\end{tabular}

Data compiled from references ${ }^{96} 97$

and are frequently frightened that any persistent symptom is a manifestation of recurrent cancer. Contacting the oncologists and surgeons at the cancer centre for precise details of previous treatments frequently changes management.

\section{History}

In addition to a detailed history relevant to the GI tract, it is important to remember that, especially after previous pelvic radiotherapy, patients will also often have other urinary, sexual, psychological and occasionally neurological symptoms which influence or are influenced by their GI problems. Bone disease (eg, pelvic insufficiency fractures) and lymphoedema are also common and may also have not been previously detected or dealt with and may be the cause for some or all of their problems. $^{90929899}$

Dietary habits-excess fibre (from 'healthy eating'), inadequate fibre, alcohol excess or unhelpful nutritional supplements (eg, excess selenium causing nausea, diarrhoea and halitosis)may contribute to or be the sole cause of chronic GI symptoms surprisingly commonly. Consultations which include input from the patient's partner often improve the quality of the history obtained.

\section{Examination, investigations and treatment}

An appropriate physical examination is required. Basic initial investigations should include haematological and biochemical profiles, inflammatory and tumour markers. In addition, clinical experience and limited published data suggest that a number of other tests are particularly worthwhile in patients who are symptomatic after cancer treatments (box 1). ${ }^{50}$

Specific investigations should be tailored for the principal symptoms and should reflect an understanding of the potential aetiologies. For example, there are at least 13 different causes for diarrhoea after pelvic radiotherapy, most of which require different treatments, and five different causes for new-onset steatorrhoea (table 5).

Faecal incontinence affects up to $50 \%$ of patients after rectal cancer and one in five patients after pelvic radiotherapy. Few

\section{Box 1 Useful initial investigations}

- Vitamin B12 levels

- Thyroid function tests

- Coeliac screen

- Selenium homocholic acid taurine (SeHCAT) scan

- Glucose hydrogen/methane breath test

- Upper GI endoscopy + duodenal aspirate

- Flexible sigmoidoscopy 
Table 5 Common physical causes for diarrhoea or steatorrhoea after cancer treatment

\begin{tabular}{ll}
\hline Diarrhoea & Steatorrhoea \\
\hline Bile acid malabsorption & Bile acid malabsorption \\
Carbohydrate malabsorption & Free fatty acid malabsorption \\
Constipation with overflow & Intestinal lymphangiectasia \\
Dietary/alcohol problems & Pancreatic insufficiency \\
Drug side effects & Small bowel bacterial overgrowth \\
Endocrine abnormalities & \\
Infection & \\
New/recurrent neoplasia & \\
New-onset primary inflammatory & \\
bowel disease & \\
Rapid transit & \\
Short bowel syndrome & \\
Small bowel bacterial overgrowth & \\
Stricture formation &
\end{tabular}

patients are referred for specialist evaluation, let alone support by incontinence services. Most commonly, evaluation is offered by coloproctologists. However, in those who have had pelvic radiotherapy or chemotherapy, faecal incontinence is often at least partly due to small bowel causes leading to intestinal hurry (especially small bowel bacterial overgrowth and bile acid malabsorption). Appropriate investigations are required when loose stool or erratic bowel function is present, and standard therapeutic approaches to faecal incontinence aimed mainly at local anorectal causes have proved to be ineffective. ${ }^{61}$

\section{Rectal bleeding from radiation-induced telangiectasia after pelvic radiotherapy}

The dose of radiotherapy delivered to the anterior rectal wall determines the risk of bleeding from telangiectasia. ${ }^{100}$ Bleeding occurs in $50 \%$ of patients after pelvic radiotherapy but impairs quality of life requiring intervention in fewer than $6 \%$. Telangiectases often heal spontaneously over 5-10 years. Patients with any rectal bleeding should be offered at least flexible sigmoidoscopy because of the high prevalence of unexpected pathology. All currently available interventions (endoscopic, surgical and hyperbaric oxygen therapy) for radiotherapyinduced bleeding are not risk-free. The only four treatments with any evidence of benefit in randomised trials (of very variable quality) are sucralfate enemas, ${ }^{101} 4$ weeks of treatment with metronidazole, ${ }^{102}$ vitamin $\mathrm{A}^{103}$ and hyperbaric oxygen therapy (figure $1 \mathrm{~A}, \mathrm{~B}){ }^{42}$
Figure 1 (A) Painful rectal ulceration following argon beam ablation for radiation-induced bleeding after treatment for prostate cancer. (B) Almost complete resolution of ulceration after 40 sessions of hyperbaric oxygen therapy.

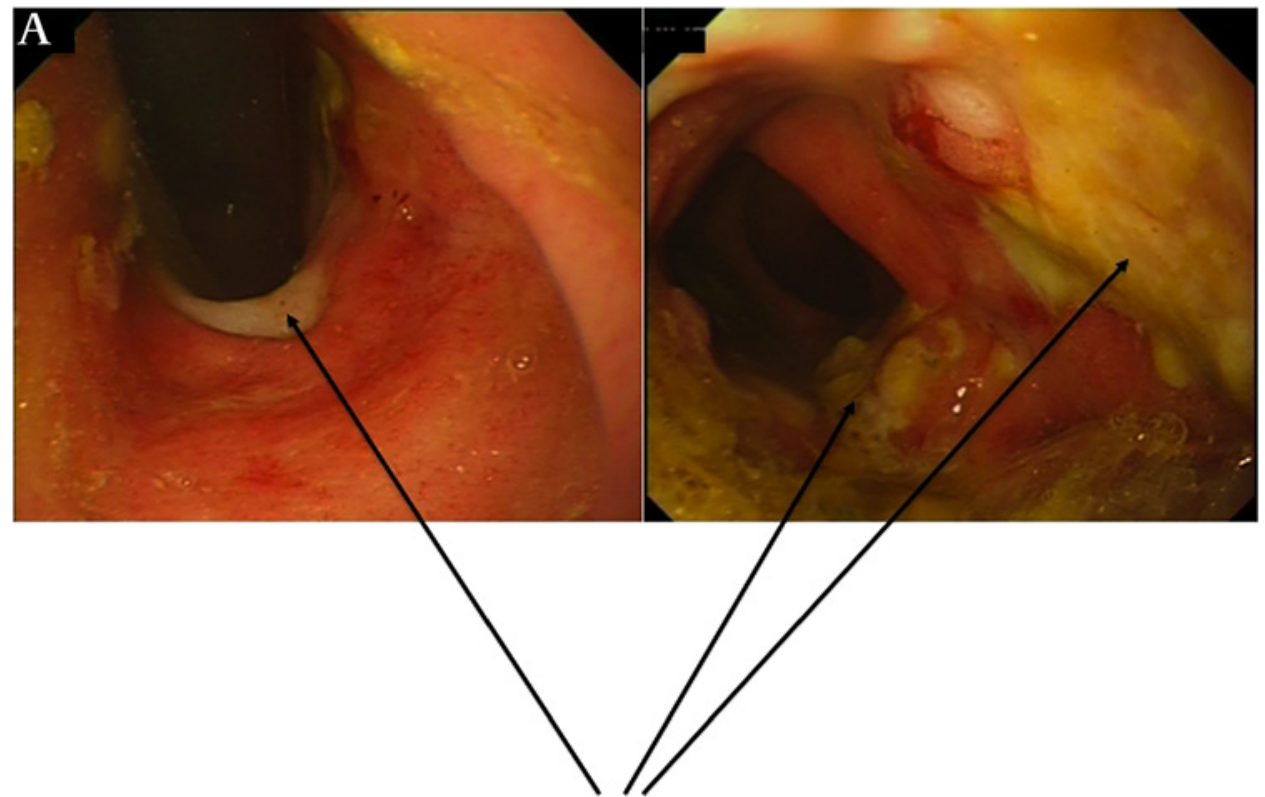

Ulceration

B

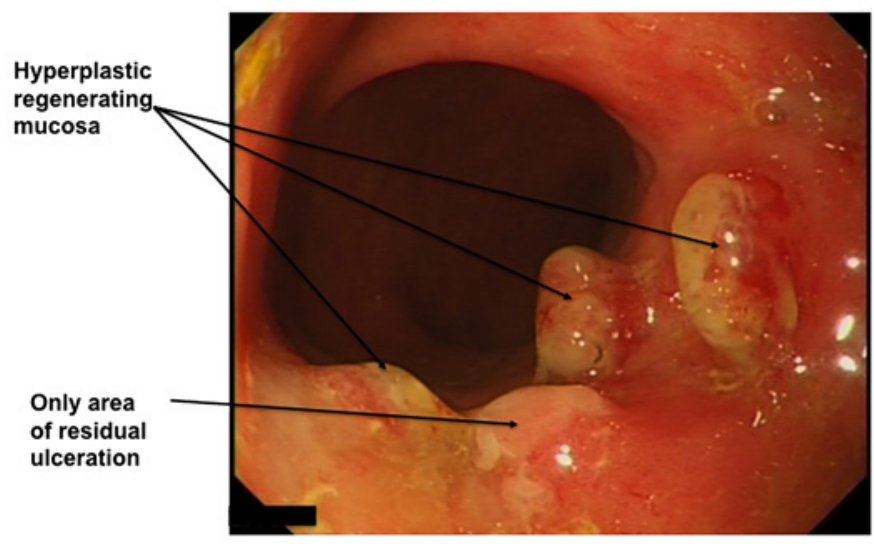


Many gastroenterologists consider that argon plasma coagulation (APC) is the treatment of choice. However, it should be used with considerable caution in this patient group. It is not widely appreciated that the published literature can be interpreted as showing that the serious complication rate for APC when used for radiation proctopathy is potentially as high as $26 \%{ }^{9} 51$ Some of these disastrous complications-such as explosions following use of APC in inadequately prepared bowel-are preventable. Others, such as the occurrence of deep ulceration, ${ }^{104-106}$ fistulation, ${ }^{107}$ stricture formation, ${ }^{104} 108109$ bleeding, ${ }^{105} 106110$ perforation ${ }^{105}$ and severe sometimes chronic pain, ${ }^{110-112}$ reflect the risk of any thermal therapy in chronically ischaemic tissues. It may be that restricting argon flow rates and wattage and very precise and brief application of the argon catheter would reduce complication rates, ${ }^{113}$ but this has not been proved. Anecdotal evidence suggests that, where bleeding is heavy, APC frequently fails. In specialist centres, serious complications of previous APC treatment in this patient group continue to be seen regularly.

The other treatment commonly prescribed is regular application of corticosteroid enemas. The evidence from randomised trials suggests minimal or no benefit from their use. ${ }^{114}$ This is unsurprising as the chronic pathophysiology of radiationinduced damage is largely ischaemic and not inflammatory. ${ }^{24}$ If topical treatment is used, sucralfate enemas (box 2) are clearly more effective than corticosteroid enemas. ${ }^{114}$

All the options for treatment of radiation-induced telangiectasia are listed in table 6. Evidence for long-term outcomes from any of the treatments is very scanty.

In the absence of any comparative studies of the various major treatment modalities of radiation-induced rectal bleeding, one clinical approach for patients with radiation-induced rectal bleeding which reduces risk to a minimum is as follows:

Step 1: Investigate with flexible endoscopy to determine the cause of the bleeding.

Step 2: Optimise bowel function and stool consistency which may reduce the amount of bleeding.

Step 3: If bleeding is not affecting quality of life (eg, staining clothes, causing anaemia, interfering with daily activities), reassure and do nothing further.

Step 4: If bleeding affects quality of life, stop/reduce anticoagulants if possible and, if very severe, start sucralfate enemas (box 2),

Step 5: Discuss definitive treatment to ablate the telangiectasia with the patient; current options include:

\section{Box 2 Making up and using sucralfate enemas}

\section{Sucralfate enemas}

- $2 \mathrm{~g}$ sucralfate suspension

- Add to 30-50 ml tap water

- Draw up in a bladder syringe

- Fit a soft Foley catheter to the syringe

- Lubricate the catheter and pass into the rectum

- Inject the sucralfate mixed with water twice a day into the rectum

- Retain the enema for as long as possible

- Initially roll through $360^{\circ}$ to coat the entire rectal surface

- Lying prone then best covers anterior wall rectal telangiectasia, the likely area of greatest bleeding

Table 6 Therapeutic options for radiation-induced rectal bleeding

\section{Treatment modality}

Medical therapies

Sucralfate enemas

Metronidazole

Sulfasalazine

Thalidomide

Short chain fatty acids

Rebampide enema therapy

Other therapies

Hyperbaric oxygen treatment

Endoscopic laser ablation

Endoscopic argon plasma coagulation

Endoscopic formalin application

Surgical application of formalin

Other references. ${ }^{6} 7116$

$\mathrm{RCT}$, randomised controlled trial.

a. hyperbaric oxygen therapy (advantages: supported by RCT evidence, may reverse progressive changes caused by radiotherapy, may improve other symptoms such as urinary problems; disadvantages: time-consuming ( 8 weeks of daily treatment), expensive and patients may need to travel long distances to their nearest unit);

b. argon plasma coagulation (advantages: easily available and simple; disadvantages: significant risk and unproven efficacy in heavy bleeding);

c. formalin therapy (advantages: simple to perform; disadvantages: long-term outcomes poorly known, small risks of serum sickness, severe proctitis or chemical burn to the skin if there is spillage).

\section{Dysphagia/retching/nausea after cancer therapies including upper $\mathbf{G l}$ surgery}

This is a common cause for referral. A suggested approach is given in table 7. Clinical experience suggests that gastric bile reflux and small bowel bacterial overgrowth are commonly forgotten causes of nausea in patients during and after cancer therapy. Strictures are often found on endoscopy and an approach to stricture management in the upper GI tract is shown in table 8 . If nausea and vomiting persist after metabolic causes have been excluded, endoscopy with or without radiology have revealed no cause and trials of routine therapy have not helped, a brain scan should be considered.

\section{Dumping syndrome}

When gastric emptying is rapid it leads to 'dumping syndrome', characterised by GI and vasomotor symptoms that occur after meals. This can be soon after meals or delayed for up to several hours. The physiological causes are complex, but include the high osmolarity of small bowel contents and reactive hypoglycaemia. The diagnosis of early dumping is usually made on clinical grounds, although rarely gastric scintigraphy is helpful. Late dumping can be diagnosed by measuring blood glucose when patients are symptomatic. If the presentation is atypical, the rare possibility of an insulinoma should be considered. Initial management should be dietary advice to reduce the volume and 
Table 7 Investigation and management of dysphagia/retching

\begin{tabular}{|c|c|c|}
\hline Investigations of choice & Differential diagnosis & Therapeutic options \\
\hline $\begin{array}{l}\text { CT+PET } \\
\text { scan } \pm \text { endoscopy }\end{array}$ & Tumour progression/recurrence & Refer back to MDT \\
\hline \multirow[t]{3}{*}{ Endoscopy } & Benign stricture & $\begin{array}{l}\text { Dilation } \pm \text { self-expanding plastic/removable metal } \\
\text { stent, long-term acid/bile suppression, dietetic } \\
\text { advice/enteral feeding tube }\end{array}$ \\
\hline & $\begin{array}{l}\text { Inflammatory (acid/bile/ } \\
\text { pepsin-related) }\end{array}$ & $\begin{array}{l}\text { Sucralfate/proton pump inhibitor/ } \\
\text { promotility agents }\end{array}$ \\
\hline & $\begin{array}{l}\text { Infection (fungal/viral small bowel } \\
\text { bacterial overgrowth) }\end{array}$ & Specific antibiotic \\
\hline \multirow[t]{2}{*}{$\begin{array}{l}\text { Radiological contrast } \\
\text { swallow } \pm \text { endoscopy }\end{array}$} & Spasm/abnormal peristalsis & $\begin{array}{l}\text { Calcium channel antagonists, low-dose } \\
\text { antidepressants }\end{array}$ \\
\hline & $\begin{array}{l}\text { Dysmotility/reflux/slow transit } \\
\text { through upper GI tract }\end{array}$ & $\begin{array}{l}\text { Sucralfate/proton pump inhibitor/promotility } \\
\text { agents (domperidone, low-dose erythromycin } \\
(250 \mathrm{mg} \text { bd), paroxetine, subcutaneous } \\
\text { naloxone), dietetic advice, enteral feeding tube }\end{array}$ \\
\hline
\end{tabular}

MDT, multidisciplinary team; PET, positron emission tomography.

osmolarity of food presented to the small intestine and the avoidance of fluids taken with meals. Loperamide, guar gum or pectin to slow gastric emptying may be helpful. For late dumping, acarbose may sometimes help. Octreotide or lanreotide are helpful in the short term. Studies have shown mixed results when these drugs were evaluated longer term. Surgical revision of the roux-en-Y anastomosis is a complex procedure but can be effective in selected cases.

\section{ROLE OF HEALTH PROFESSIONALS IN THE LATE EFFECTS TEAM}

Cancer clinical nurse specialists (CNS) are ideally placed to undertake the end of treatment assessment with the patient. The CNS is usually in contact with the patient throughout their cancer journey. They undertake a key role in the liaison with all members of the multidisciplinary team as well as care providers in the community or referring units. They will be available to offer support and information to patients and their carers and increasingly take on a 'key worker' role ensuring the smooth running of the patient pathway.

The CNS is an autonomous practitioner who may run their own nurse-led clinics during treatment or in follow-up and many continue to develop their role, taking on advanced assessment and prescribing as part of their practice. They should encourage patients to seek help for any new symptoms. It is essential that they are able to recognise those with ongoing effects of their therapy so they can identify them to the oncologist and to support referral for gastroenterological opinion.

Patients who are well informed about their disease and its treatment, the possible effects they may experience and services available to help and support them have a greater chance of achieving a better quality of life within the constraints of their

Table 8 Endoscopic management of oesophageal strictures ${ }^{117}$

\begin{tabular}{ll}
\hline Nature of stricture & Advice \\
\hline Anastomotic/tumour/ & Should be performed only by experienced endoscopists \\
radiation & If tumour is present, endoscopic intervention \\
& should only occur after MDT discussion \\
& Dilate to a maximum diameter of $15-20 \mathrm{~mm}$ \\
& Dilate for $20-60 \mathrm{~s}$ if using a balloon \\
& Dilation $>12 \mathrm{~mm}$ not required for stent insertion \\
& Do not exceed diameter of the stricture by \\
& $>7-8 \mathrm{~mm}$ per session \\
& Risks are increased after chemotherapy/radiotherapy/if \\
& tumour is presentTemporary/permanent stent placement \\
& may be required after dilation \\
\hline
\end{tabular}

condition. Many sources of information are available to patients, but they may need direction to information that is of a high quality and is relevant to them; they may need help to interpret the information. They should be offered information in a language and format that is acceptable to them so that they can make decisions regarding their care and condition where possible. It may also be helpful to direct patients to local support groups where they exist.

Specialist dietetic help is often required (boxes 4 and 6). Weight loss and weight gain (the metabolic syndrome) can be problems after cancer treatment. However, new groups at risk are frequently being defined. As many as $40 \%$ of patients with metastatic colorectal cancer at presentation have lost significant amounts of weight and have not regained it at 1 year. ${ }^{118}$ About $10 \%$ of patients develop very severe toxicity (mostly bowel toxicity) after chemoradiation for cervical cancer, which can lead to significant nutritional issues. ${ }^{119}$

Often these patients have complex causes for their symptoms which need multiple investigations by the gastroenterologist, ${ }^{51}$ and then joint management by the gastroenterologist and dietitian (box 3) which may include dietary fibre manipulation, reduced fat diets and changes in carbohydrate intake, especially lactose and fructose. In these patients, dietary adequacy and mineral and vitamin status are often compromised and need formal assessment and, if necessary, treatment with dietary advice or specific micronutrient supplements.

Box 3 An approach to other common problems after pelvic radiotherapy

\section{Mucus discharge/leakage}

- Ensure that fibre intake is not excessive

- Provide pelvic floor and toileting exercises

- Stool bulking agent and/or antidiarrhoeal agent

Excess rectal flatulence

Consider:

1. Dietary: excess/deficiency of fibre intake and inadequate fluid intake

2. Colonic faecal loading

3. Small intestinal bacterial overgrowth

4. Organic cause (eg, neoplasia, inflammatory bowel disease) 


\section{Box 4 Research priorities}

\section{Important research themes}

- How are patients with chronic GI effects of cancer therapies best detected?

- What are the best objective tools to measure the severity of chronic gastrointestinal problems?

- What are the best objective biomarkers of damage to non-cancerous tissues?

- What are the frequency and nature of chronic Gl symptoms after different cancer treatments which affect patients' day to day activities?

- How can quality of life scores be used to quantitate ongoing symptoms?

-Who should manage chronic symptoms?

- By what stage should patients be referred for specialist evaluation?

- What treatments work for late side effects?

- How are chronic side effects best prevented?

\section{Important achievable clinical trials which are urgently required}

- Randomised trials of optimal therapy for faecal incontinence/anterior resection syndrome after surgery

- Randomised trials of conservative treatment versus hyperbaric oxygen/argon plasma coagulation/intrarectal formalin for radiationinduced bleeding

- Randomised trials of nurse-led management versus doctor-delivered care for GI late effects

- Randomised trials of promotility agents for gastroparesis after upper Gl surgery

- Randomised trials of antifibrotic agents soon after completion of radiotherapy to ameliorate chronic progressive fibrosis and hence symptoms

- Randomised trials of PEG feeding versus nasogastric tube feeding to prevent chronic feeding problems in patients undergoing treatment for head and neck malignancy

High quality clinical series which will quickly impact clinical outcomes

- What are the physiological abnormalities which accompany chemotherapy-induced diarrhoea (eg, lactose intolerance, bile acid malabsorption, small bowel bacterial overgrowth)?

- Small bowel bacterial overgrowth after cancer treatment, what organisms and when?

\section{Important unanswered questions}

- Outcomes of low-fibre diets for intermittent small bowel obstruction

- Role of low-fat diets in patients with steatorrhoea

\section{CONCLUSIONS}

Substantial progress has been made in treating cancer. However, there are convincing and consistent data that large numbers of people have chronic physical morbidity after cancer treatment which commonly affects the GI tract and impacts adversely on daily activities. There is a professional obligation to identify systematically patients with such unmet needs and to develop appropriate referral pathways where they do not currently exist.
This multidisciplinary guidance is designed to help those clinicians who wish to understand better the underlying pathology and current management options for physical symptoms. It is hoped that it may form the starting point for multidisciplinary team discussions to enhance care for these patients and for educational programmes for trainees who need to know how to manage these issues. Systematic education about the optimal management of severely symptomatic

\section{Box 5 Clinicians beware!}

\section{Clinicians beware!}

- Fixed, impassable and easily perforated sigmoid on endoscopy in patients with gynaecological cancer after combination chemotherapy + radiation \pm surgery.

- Endoscopic biopsy of the anterior rectal wall in patients who have had brachytherapy is associated with a $2 \%$ rate of fistula formation

- Mesalazine exacerbates acute radiation-induced intestinal inflammation

- There is minimal chronic inflammation after radiotherapy so corticosteroids have no role in the management of chronic symptoms

- Patients with steatorrhoea are usually misdiagnosed as having diarrhoea

- Hepatic veno-occlusive disease is an emergency

- Small bowel bacterial overgrowth can cause any Gl symptom including subacute obstruction

- Tissues which have been exposed to radiation may not heal normally after biopsy or polypectomy

- Endoscopic or surgical intervention in irradiated tissues is an intervention within a potentially ischaemic field

- There is a reported rate of serious complications of $7-26 \%$ for argon beam ablation of rectal radiation-induced telangiectasia

- Only two treatments have been shown with any degree of conviction in controlled trials to be effective for radiation-induced rectal bleeding from telangiectasia: sucralfate enemas and hyperbaric oxygen therapy

- Don't forget common medical causes of recurrent subacute obstruction

- Low levels of faecal elastase only diagnoses pancreatic insufficiency reliably after small bowel bacterial overgrowth has been excluded 


\section{Box 6 Dietetic requirements for patients after cancer} treatment

- Patients should be managed by registered dietitians

- Implement a time-limited trial of dietary changes

- Routinely assess patients with malabsorption for dietary adequacy

- Do not prescribe long-term dietary restriction(s) that provide no benefit

- Monitor nutritional status (weight, anthropometry, vitamin and trace element levels)

patients is sorely lacking, despite the fact that the number of affected patients in the UK currently equals the number of patients diagnosed annually with primary inflammatory bowel disease, and is increasing by $3 \%$ per year. This patient group can undoubtedly gain substantial benefit from a more coherent approach to care for their ongoing and often disabling and distressing symptoms.

Acknowledgments The authors thank Dr lan Chau, Dr Johann de Bono, Dr lan Geh, Dr Simon Greenfield, Patrice Kennedy, Mr Brendan Moran, Miss Sarah O'Dwyer, Mr Graeme Poston, Dr Clare Shaw, Dr Diana Tait, Dr Mark Wilkinson and anonymous referees from ACPGBI, AUGIS, BSG and the RCR Faculty of Clinical Oncology for thoughtful and constructive input into this document.

Competing interests None.

Contributors All authors met before the guidance was written and discussed the format of the guidance, its content and what should not be included. Sections of the guidance were given to each author to research and write. JA edited the initial submissions which were further edited by ES. The writing committee reviewed this completed draft, suggestions were discussed and a further major revision of the manuscript was undertaken by JA and edited a second time by ES. This second major revision was sent out for comments to the four collaborating societies (the Association of Colo-Proctology of Great Britain and Ireland, the Association of Upper Gastrointestinal Surgeons, the British Society of Gastroenterology and the Royal College of Radiologists). These societies all commissioned at least two reviewers to read and comment on the manuscript. In addition, JA and ES sent copies of the manuscript to known specialists with expertise in this field as listed in the acknowledgements and asked them for comments. The penultimate draft of the manuscript was produced after taking all comments into account by JA and ES, circulated around the members of the writing committee and a final agreed version was produced which is the submitted version.

Provenance and peer review Not commissioned; externally peer reviewed.

\section{REFERENCES}

1. National Cancer Survivorship Initiative Vision. 2010. http://www.nsci.org.uk.

2. Gelber R, Goldhirsch A, Cole B, et al. A quality-adjusted time without symptoms or toxicity (Q-TWiST) analysis of adjuvant radiation therapy and chemotherapy for resectable rectal cancer. J Natl Cancer Inst 1996;88:1039-45.

3. Andreyev HJ. Gastrointestinal problems following pelvic radiotherapy: the past, the present and the future. Clin Oncol (R Coll Radiol) 2007;19:790-9.

4. Bacon C, Giovannucci E, Testa M, et al. The association of treatment-related symptoms with quality-of-life outcomes for localized prostate carcinoma patients. Cancer 2002; 94:862-71

5. Andreyev HJ, Amin Z, Blake P, et al. Gl symptoms developing after pelvic radiotherapy require gastroenterological review but is that happening in the UK? (Abstract) Clin Oncol 2003;15:S12.

6. Denton A, Bentzen S, Maher E. How useful are observational reports in the evaluation of interventions for radiation morbidity? An analysis of formalin therapy for late radiation proctitis. Radiother Oncol 2002;44:291-5.

7. Denton AS, Forbes AL, Andreyev HJ, et al. Non-surgical interventions for late radiation proctitis in patients who have received radical radiotherapy to the pelvis. Cochrane Database Syst Rev 2002:1:CD003455.

8. Vicary P, Johnson M, Maher J; Patient representatives of the Macmillan Late Effects Project Group. To my oncologist - an open letter from a patient at the end of follow-up. Clin Oncol (R Coll Radiol) 2007:19:746-7.

9. Andreyev HJ. Argon plasma coagulation in chronic radiation proctitis. Endoscopy 2007:39:751-2.
10. Faithfull S. 'Just grin and bear it and hope that it will go away': coping with urinary symptoms from pelvic radiotherapy. Eur J Cancer Care (Engl) 1995;4:158-65.

11. Beck KE, Blansfield JA, Tran KQ, et al. Enterocolitis in patients with cancer after antibody blockade of cytotoxic T-lymphocyte-associated antigen 4. J Clin Oncol 2006;24:2283-9.

12. Alexandrescu DT, Dutcher JP, Wiernik PH. Capecitabine-induced pancolitis. Int $J$ Colorectal Dis 2007:22:455

13. Kaur H, Loyer EM, David CL, et al. Radiologic findings in taxane induced colitis. Eur J Radiol 2008:66:75-8.

14. Osterlund $\mathbf{P}$, Ruotsalainen T, Peuhkuri $\mathrm{K}$, et al. Lactose intolerance associated with adjuvant 5-fluorouracil-based chemotherapy for colorectal cancer. Clin Gastroenterol Hepatol 2004:2:696-703.

15. Parnes HL, Fung E, Schiffer CA. Chemotherapy-induced lactose intolerance in adults. Cancer 1994;74:1629-33.

16. Andreyev HJ. A physiological approach to modernize the management of cancer chemotherapy-induced gastrointestinal toxicity. Curr Opin Support Palliat Care 2010:4:19-25.

17. Artz AS, Somerfield MR, Feld JJ, et al. American Society of Clinical Oncology provisional clinical opinion: chronic hepatitis B virus infection screening in patients receiving cytotoxic chemotherapy for treatment of malignant diseases. J Clin Oncol 2010;28:3199-202.

18. Rubbia-Brandt L, Audard V, Sartoretti P, et al. Severe hepatic sinusoidal obstruction associated with oxaliplatin-based chemotherapy in patients with metastatic colorectal cancer. Ann Oncol 2004;15:460-6.

19. Vauthey JN, Pawlik TM, Ribero D, et al. Chemotherapy regimen predicts steatohepatitis and an increase in 90-day mortality after surgery for hepatic colorectal metastases. J Clin Oncol 2006;24:2065-72.

20. Zorzi D, Laurent A, Pawlik TM, et al. Chemotherapy-associated hepatotoxicity and surgery for colorectal liver metastases. Br J Surg 2007;94:274-86.

21. Kishi Y, Zorzi D, Contreras CM, et al. Extended preoperative chemotherapy does not improve pathologic response and increases postoperative liver insufficiency after hepatic resection for colorectal liver metastases. Ann Surg Oncol 2010;17:2870-6.

22. Chun YS, Laurent A, Maru D, et al. Management of chemotherapy-associated hepatotoxicity in colorectal liver metastases. Lancet Oncol 2009;10:278-86.

23. Di Fiore F, Van Cutsem E. Acute and long-term gastrointestinal consequences of chemotherapy. Best Pract Res Clin Gastroenterol 2009;23:113-24.

24. Denham JW, Hauer-Jensen M. The radiotherapeutic injury-a complex 'wound'. Radiother Oncol 2002:63:129-45.

25. Hanlon AL, Schultheiss TE, Hunt MA, et al. Chronic rectal bleeding after high-dose conformal treatment of prostate cancer warrants modification of existing morbidity scales. Int J Radiat Oncol Biol Phys 1997:38:59-63.

26. Veldeman L, Madani I, Hulstaert F, et al. Evidence behind use of intensitymodulated radiotherapy: a systematic review of comparative clinical studies. Lancet Oncol 2008:9:367-75. Erratum in Lancet Oncol 2008:9(6):513.

27. Al-Mamgani A, Heemsbergen WD, Peeters ST, et al. Role of intensity-modulated radiotherapy in reducing toxicity in dose escalation for localized prostate cancer. Int J Radiat Oncol Biol Phys 2009;73:685-91.

28. Fiorino C, Valdagni R, Rancati T, et al. Dose-volume effects for normal tissues in external radiotherapy: pelvis. Radiother Oncol 2009:93:153-67.

29. National Chemotherapy Advisory Group. Chemotherapy Services in England: Ensuring Quality and Safety. 2009. http://www.dh.gov.uk/prod_consum dh/groups/ dh digitalassets/documents/digitalasset/dh 104501.pdf

30. Allison MC, Sandoe JA, Tighe R, et al. Antibiotic prophylaxis in gastrointestinal endoscopy. Gut 2009;58:869-80.

31. Cotte L, Rabodonirina M, Piens MA, et al. Prevalence of intestinal protozoans in French patients infected with HIV. J Acquir Immune Defic Syndr 1993;6: 1024-9.

32. Blanshard C, Francis N, Gazzard BG. Investigation of chronic diarrhoea in acquired immunodeficiency syndrome. A prospective study of 155 patients. Gut 1996;39:824-32.

33. Patel SM, Cohen P, Pickering MC, et al. Successful treatment of acute haemorrhagic cytomegalovirus colitis with ganciclovir in an individual without overt immunocompromise. Eur J Gastroenterol Hepatol 2003:15:1055-60.

34. Reddy N, Wilcox CM. Diagnosis and management of cytomegalovirus infections in the Gl tract. Expert Rev Gastroenterol Hepatol 2007:1:287-94.

35. Nomura K, Fujimoto Y, Yamashita, et al. Absence of pseudomembranes in Clostridium difficile-associated diarrhea in patients using immunosuppression agents. Scand J Gastroenterol Suppl 2009:44:74-8.

36. Davila ML. Neutropenic enterocolitis. Curr Opin Gastroenterol 2006;22:44-7.

37. Li Z, Ibrahim NK, Wathen JK, et al. Colitis in patients with breast carcinoma treated with taxane-based chemotherapy. Cancer 2004:101:1508-13.

38. Schellhaas E, Loddenkemper C, Schmittel A, et al. Bowel perforation in non-small cell lung cancer after bevacizumab therapy. Invest New Drugs 2009:27:184-7.

39. Slade JH, Alattar ML, Fogelman DR, et al. Portal hypertension associated with oxaliplatin administration: clinical manifestations of hepatic sinusoidal injury. Clin Colorectal Cancer 2009;8:225-30.

40. Feldmeier $\mathbf{J}$, Hampson N. A systematic review of the lterature reporting the application of hyperbaric oxygen prevention and treatment of delayed radiation injuries: an evidence based approach. Undersea Hyperb Med 2002;29:4-30.

41. Bennett M, Feldmeier J, Hampson N, et al. Hyperbaric oxygen therapy for late radiation tissue injury. Cochrane Database Syst Rev 2005;(3):CD005005. 
42. Clarke RE, Tenorio LM, Hussey JR, et al. Hyperbaric oxygen treatment of chronic refractory radiation proctitis: a randomized and controlled double-blind crossover trial with long-term follow-up. Int J Radiat Oncol Biol Phys 2008:72:134-43

43. Hapani S, Chu D, Wu S. Risk of gastrointestinal perforation in patients with cancer treated with bevacizumab: a meta-analysis. Lancet Oncol 2009:10:559-68.

44. Cennamo V, Fuccio L, Mutri V, et al. Does stent placement for advanced colon cancer increase the risk of perforation during bevacizumab-based therapy? Clin Gastroenterol Hepatol 2009:7:1174-6.

45. Lee AY, Levine MN. The thrombophilic state induced by therapeutic agents in the cancer patient. Semin Thromb Hemost 1999;25:137-45.

46. Richardson P, Guinan E. Hepatic veno-occlusive disease following hematopoietic stem cell transplantation. Acta Haematol 2001;106:57-68.

47. Breitenstein S, Rickenbacher A, Berdajs D, et al. Systematic evaluation of surgical strategies for acute malignant left-sided colonic obstruction. Br J Surg 2007:94:1451-60.

48. Roeland $\mathbf{E}$, von Gunten CF. Current concepts in malignant bowel obstruction management. Curr Oncol Rep 2009;11:298-303.

49. Capp A, Inostroza-Ponta M, Bill D, et al. Morbidity of prostate radiotherapy: is there more than one proctitis syndrome? A revisitation using data from the TROG 96.01 trial. Radiother Oncol 2009;90:400-7.

50. Andreyev HJ, Vlavianos P, Blake P, et al. Gastrointestinal symptoms after pelvic radiotherapy: is there any role for the gastroenterologist? Int J Radiol Biol Phys 2005; 62:1464-71.

51. Andreyev HJ. Gastrointestinal symptoms following therapeutic pelvic radiotherapy: a new understanding to improve the management of symptomatic patients. Lancet Oncol 2007;8:1007-17

52. den Hartog Jager F, van Haastert M, Batterman J, et al. The endoscopic spectrum of late radiation damage of the recto-sigmoid colon. Endoscopy 1985; 17:214-16.

53. Moore E, Magrino T, Johnstone P. Rectal bleeding after radiation therapy for prostate cancer: endoscopic evaluation. Radiology 2000;217:215-18.

54. Wachter S, Gerstner N, Goldner G, et al. Endoscopic scoring of late rectal mucosal damage after conformal radiotherapy for prostatic carcinoma. Radiother Oncol 2000;54:11-19

55. Williams HR, Vlavianos $P$, Blake $P$, et al. The significance of rectal bleeding after pelvic radiotherapy. Aliment Pharmacol Ther 2005;21:1085-90.

56. Davidson SE, Burns MP, Routledge JA, et al. Assessment of morbidity in carcinoma of the cervix: a comparison of the LENT SOMA scales and the FrancoItalian Glossary. Radiother Oncol 2003;69:195-200.

57. Davidson S, Faithfull S. Late radiotherapy effects: is bowel morbidity adequately documented or patients' needs managed appropriately? Clin Oncol (R Coll Radiol) 2006;18:419-20

58. Davidson SE, Trotti A, Ataman OU, et al. Improving the capture of adverse event data in clinical trials: the role of the International Atomic Energy Agency. Int J Radiat Oncol Biol Phys 2007;69:1218-21.

59. Pedersen D, Bentzen SM, Overgaard J. Early and late radiotherapeutic morbidity in 442 consecutive patients with locally advanced carcinoma of the uterine cervix. Int $J$ Radiat Oncol Biol Phys 1994;29:941-52.

60. Denton AS, Bond SJ, Matthews S, et al. National audit of the management and outcome of carcinoma of the cervix treated with radiotherapy in 1993. Clin Oncol (R Coll Radiol) 2000;12:347-53 and comment: 3-6.

61. Putta S, Andreyev HJ. Faecal incontinence-a late side effect of pelvic radiotherapy. Clin Oncol 2005; 7:469-77

62. Yeoh E, Botten R, Russo A, et al. Chronic effects of therapeutic irradiation for localised prostatic carcinoma on anorectal function. Int J Radiat Oncol Biol Phys 2000;47:915-24

63. Olopade FO, Norman AR, Blake $\mathrm{P}$, et al. The inflammatory bowel disease questionnaire and the Vaizey incontinence questionnaire are useful to identify gastrointestinal toxicity after pelvic radiotherapy. Br J Cancer 2005;92:1663-70.

64. Wedlake L, A'Hern $\mathrm{R}$, Russell $\mathrm{D}$, et al Systematic review: the prevalence of idiopathic bile acid malabsorption as diagnosed by SeHCAT scanning in patients with diarrhoea-predominant irritable bowel syndrome. Aliment Pharmacol Ther 2009;30:707-17.

65. Andreyev HJ, Wotherspoon A, Denham JD, et al. Defining pelvic-radiation disease for the survivorship era. Lancet Oncol 2010;11:310-12.

66. Christie D, Denham JW, Steigler A, et al. Delayed rectal and urinary symptomatology in patients treated for prostate cancer by radiotherapy with or without short term neo-adjuvant androgen deprivation. Radiother Oncol 2005; 77:117-25

67. West CM, Davidson SE. Measurement tools for gastrointestinal symptoms in radiation oncology. Curr Opin Support Palliat Care 2009:3:36-40.

68. NHS. An Audit of the Care Received by People with Oesophago-Gastric Cancer in England and Wales. Second Annual Report. http://www.ic.nhs.uk/webfiles/ Services/NCASP/Cancer/New\%20web\%20documents\%20(0G)/28010208-NHSICOGAuditReport-FV-HR.pdf

69. Lerut T, Van Lanschot J. Chronic symptoms after subtotal or partial oesophagectomy: diagnosis and treatment. Best Pract Res Clin Gastroenterol 2004; 18:901-15.

70. Parameswaran R, McNair A, Avery KN, et al. The role of health-related quality of life outcomes in clinical decision making in surgery for esophageal cancer: a systematic review. Ann Surg Oncol 2008;15:2732-9.
71. NHS Executive. Improving Outcomes in Upper Gastro-Intestinal Cancers. 2001 http://www.dh.gov.uk/prod_consum_dh/groups/dh_digitalassets/@dh/@en/ documents/digitalasset/dh 4080278. df

72. Neoptolemos J, Büchler $\bar{M}$, Stocken DD, et al. ESPAC-3(v2): a multicenter, international, open-label, randomized, controlled phase III trial of adjuvant 5 -fluorouracil/folinic acid (5-FU/FA) versus gemcitabine (GEM) in patients with resected pancreatic ductal adenocarcinoma. J Clin Oncol 2009;27:LBA4505.

73. Ho YH, Low D, Goh HS. Bowel function survey after segmental colorectal resections. Dis Colon Rectum 1996;39:307-10.

74. Lange MM, den Dulk M, Bossema ER, et al. Risk factors for faecal incontinence after rectal cancer treatment. Br J Surg 2007;94:1278-84.

75. Urso E, Serpentini S, Pucciarelli S, et al. Complications, functional outcome and quality of life after intensive preoperative chemoradiotherapy for rectal cancer. Eur $J$ Surg Oncol 2006;32:1201-8.

76. Hauer-Jensen $\mathbf{M}$, Wang J, Denham JW. Bowel injury: current and evolving management strategies. Semin Radiat Oncol 2003;13:357-71.

77. Al-0thman MO, Amdur RJ, Morris CG, et al. Does feeding tube placement predict for long-term swallowing disability after radiotherapy for head and neck cancer? Head Neck 2003;25:741-7.

78. Ho KF, Farnell DJ, Routledge JA, et al. Developing a CTCAEs patient questionnaire for late toxicity after head and neck radiotherapy. Eur J Cancer Care 2009:45:1992-8.

79. Denis F, Garaud P, Bardet E, et al. Final results of the 94-01 French Head and Neck Oncology and Radiotherapy Group randomized trial comparing radiotherapy alone with concomitant radiochemotherapy in advanced-stage oropharynx carcinoma. J Clin Oncol 2004:22:69-76.

80. Frykholm GJ, Glimelius B, Påhlman L. Preoperative or postoperative irradiation in adenocarcinoma of the rectum: final treatment results of a randomized trial and an evaluation of late secondary effects. Dis Colon Rectum 1993;36:564-72.

81. Kollmorgen C, Meagher A, Wolff B, et al. The long-term effect of adjuvant postoperative chemoradiotherapy for rectal carcinoma on bowel function. Ann Surg 1994;220:676-82

82. Letschert JG, Lebesque JV, Aleman BM, et al. The volume effect in radiationrelated late small bowel complications: results of a clinical study of the EORTC Radiotherapy Cooperative Group in patients treated for rectal carcinoma. Radiother Oncol 1994;32:116-23.

83. Lundby L, Jensen V, Overgaard J, et al. Long-term colorectal function after postoperative radiotherapy for colorectal cancer. Lancet 1997;350:564.

84. Lundby L, Krogh K, Jensen V, et al. Long-term anorectal dysfunction after postoperative radiotherapy for rectal cancer. Dis Colon Rectum 2005;48:1343-52.

85. Dahlberg M, Glimelius B, Graf W, et al. Preoperative irradiation affects functional results after surgery for rectal cancer. Dis Colon Rectum 1998;41:543-51.

86. Miller A, Martenson J, Nelson $\mathrm{H}$, et al. The incidence and clinical consequences of treatment-related bowel injury. Int J Radiat Oncol Biol Phys 1999;43:817-25.

87. Sauer R, Becker $\mathrm{H}$, Hohenberger W, et al. Preoperative versus postoperative chemoradiotherapy for rectal cancer. N Engl J Med 2004;351:1731-40.

88. Peeters KC, van de Velde CJ, Leer JW, et al. Late side effects of short-course preoperative radiotherapy combined with total mesorectal excision for rectal cancer: increased bowel dysfunction in irradiated patients-a Dutch colorectal cancer group study. J Clin Oncol 2005:23:6199-206.

89. Marijnen CA, van de Velde CJ, Putter $\mathrm{H}$, et al. Impact of short-term preoperative radiotherapy on health-related quality of life and sexual functioning in primary rectal cancer: report of a multicenter randomized trial. J Clin Oncol 2005;23:1847-58

90. Pollack J, Holm T, Cedermark B, et al. Late adverse effects of short-course preoperative radiotherapy in rectal cancer. Br J Surg 2006;93:1519-25.

91. Pietrzak L, Bujko K, Nowacki MP, et al. Quality of life, anorectal and sexual functions after preoperative radiotherapy for rectal cancer: report of a randomised trial. Radiother Oncol 2007;84:217-25.

92. Birgisson H, Påhlman L, Gunnarsson U, et al. Late adverse effects of radiation therapy for rectal cancer-a systematic overview. Acta Oncol 2007:46:504-16.

93. Birgisson H, Påhlman L, Gunnarsson U, et al. Late gastrointestinal disorders after rectal cancer surgery with and without preoperative radiation therapy. $\mathrm{Br} J$ Surg 2008:95:206-13.

94. Zentler-Munro P, Bessell E. Medical management of radiation enteritis-an algorithmic guide. Clin Radiol 1987;38:291-4

95. Theis VS, Sripadam R, Ramani V, et al. Chronic radiation enteritis. Clin Oncol 2010;22:70-83

96. CG58 Prostate Cancer: NICE Guidance. 2008. http://www.nice.org.uk/nicemedia/ pdf/CG58NICEGuidelinepdf

97. National Institute of Clinical Excellence. Faecal Incontinence: the Management of Faecal Incontinence in Adults. 2007. http://www.nice.org.uk/49

98. Lange MM, Maas CP, Marijnen CA, et al. Urinary dysfunction after rectal cancer treatment is mainly caused by surgery. Br J Surg 2008:95:1020-8.

99. Lange MM, Marijnen CA, Maas CP, et al. Risk factors for sexual dysfunction after rectal cancer treatment. Eur J Cancer 2009;45:1578-88.

100. Sanguineti G, Franzone P, Marcenaro M, et al. Sucralfate versus mesalazine versus hydrocortisone in the prevention of acute radiation proctitis during conformal radiotherapy for prostate carcinoma. A randomized study. Strahlenther Onkol 2003:179:464-70.

101. Cavcic J, Turcic J, Martinac P, et al. Metronidazole in the treatment of chronic radiation proctitis: clinical trial. Croat Med J 2000;41:314-18. 
102. Ehrenpreis $\mathbf{E}$, Jani A, Levitsky J, et al. A prospective, randomized, double-blind, placebo-controlled trial of retinol palmitate (vitamin A) for symptomatic chronic radiation proctopathy. Dis Colon Rectum 2005;48:1-8.

103. Talley NA, Chen F, King D, et al. Short-chain fatty acids in the treatment of radiation proctitis: a randomized, double-blind, placebo-controlled, cross-over pilot trial. Dis Colon Rectum 1997:40:1046-50.

104. Fenwick JD, Khoo VS, Nahum AE, et al. Correlation between surface dose histograms and the incidence of long term rectal bleeding following conformal or conventional radiotherapy treatment of prostate cancer. Int J Radiat Oncol Biol Phys 2001;49:437-80

105. Taieb S, Rolachon A, Cenni JC, et al. Effective use of argon plasma coagulation in the treatment of severe radiation proctitis. Dis Colon Rectum 2001:44:1766-71.

106. Canard JM, Védrenne B, Bors G, et al. Long term results of treatment of hemorrhagic radiation proctitis by argon plasma coagulation. Gastroenterol Clin Biol 2003;27:455-9.

107. Dees J, Meijssen MA, Kuipers EJ. Argon plasma coagulation for radiation proctitis Scand J Gastroenterol Supp/ 2006;243:175-8.

108. Rotondano G, Bianco MA, Marmo R, et al. Long-term outcome of argon plasma coagulation therapy for bleeding caused by chronic radiation proctopathy. Dig Liver Dis 2003:35:806-10.

109. Tam W, Moore J, Schoeman M. Treatment of radiation proctitis with argon plasma coagulation. Endoscopy 2000;32:667-72.

110. Zinicola R, Rutter MD, Falasco G, et al. Haemorrhagic radiation proctitis: endoscopic severity may be useful to guide therapy. Int $\mathrm{J}$ Colorectal Dis 2003:18:439-44.
111. Venkatesh KS, Ramanujam P. Endoscopic therapy for radiation proctitis-induced hemorrhage in patients with prostatic carcinoma using argon plasma coagulator application. Surg Endosc 2002;16:707-10.

112. Villavicencio RT, Rex DK, Rahmani E. Efficacy and complications of argon plasma coagulation for hematochezia related to radiation proctopathy. Gastrointest Endosc 2002; 55:70-4.

113. Sebastian S, O'Connor H, O'Morain C, et al. Argon plasma coagulation as first-line treatment for chronic radiation proctopathy. J Gastroenterol Hepatol 2004:19:1169-73

114. Sato $\mathbf{Y}$, Takayama $T$, Sagawa $T$, et al. Argon plasma coagulation treatment of hemorrhagic radiation proctopathy: the optimal settings for application and longterm outcome. Gastrointest Endosc 2011:73:543-9.

115. Denton A, Andreyev HJ, Forbes A, et al. Systematic review for non-surgical interventions for the management of late radiation proctitis. $\mathrm{Br} \mathrm{J}$ Cancer 2002;87:134-43.

116. Cullen S, Frenz M, Mee A. Treatment of haemorrhagic radiation-induced proctopathy using small volume topical formalin instillation. Aliment Pharmacol Ther 2006;23:1575-9.

117. Riley SA, Attwood SE. Guidelines on the use of oesophageal dilatation in clinica practice. Gut 2004;53(Suppl 1):1-6.

118. Baldwin C, McGough C, Norman AR, et al. Failure of dietetic referral in patients with gastrointestinal cancer and weight loss. Eur J Cancer Care 2006;42:2504-9.

119. Vale CL, Tierney JF, Davidson SE, et al. Substantial improvement in UK cervical cancer survival with chemoradiotherapy:results of a Royal College of Radiologists' audit. Clin Oncol 2010;22:590-601.

\section{Advancing} Postgraduates. Enhancing Healthcare.

The Postgraduate Medical Journal is dedicated to advancing the understanding of postgraduate medical education and training.

- Acquire the necessary skills to deliver the highest possible standards of patient care

- Develop suitable training programmes for your trainees

- Maintain high standards after training ends

Published on behalf of the fellowship for Postgraduate Medicine

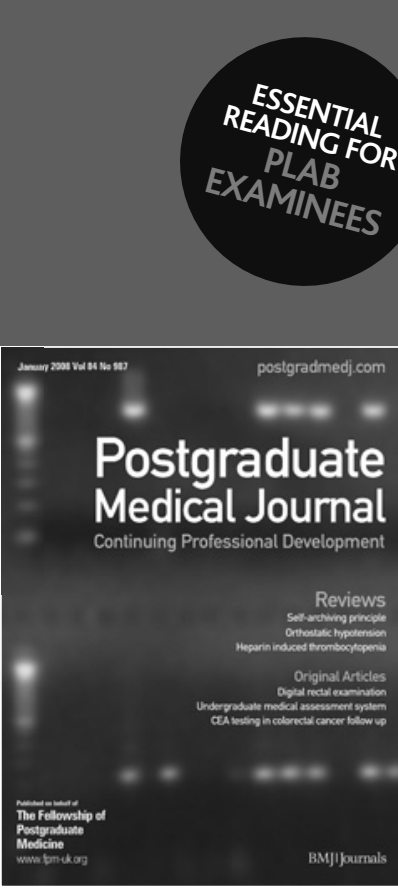

FOR MORE DETAILS OR TO SUBSCRIBE, VISIT THE WEBSITE TODAY

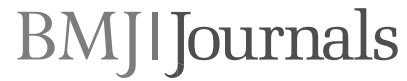

\section{postgradmedj.com}

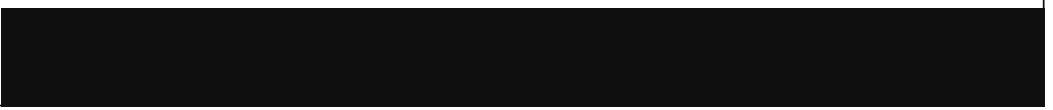

